\title{
Tutkitun tiedon ja tutkijoiden huomioiminen lainsäädäntö- työssä. Esimerkkinä tyttöjen sukuelinten silpomisen lainsäädäntöuudistus.
}

Tiedolla johtamisen teorioita ja malleja on useita. Yksinkertaistettuna tiedolla johtaminen tarkoittaa sitä, että tietoa analysoidaan systemaattisesti hyödynnettäväksi päätöksenteossa. Tiedolla johtamisen perusprosessi noudattaa pitkälti tutkimuksen teon prosessia lähtien ongelman määrittelystä ja päätyen vaikuttavuuden arviointiin.

Kuten Sosiaalilääketieteellisen aikakauslehden aiemmissa Tieteestä politiikkaa -puheenvuoroissa on kirjoitettu, päätösten tulisi aina pohjautua tietoon. Tyttöjen ja naisten sukuelinten silpomisen (female genital mutilation, FGM) tai ympärileikkauksen nykyistä tiukemmaksi säätelemiseksi tehtiin kansalaisaloite, joka johti lainsäädännön uudistamiseen. Tässä puheenvuorossa kuvaan prosessia ja pohdin, minkä verran tieto ohjasi sitä - mikä oli tutkijoiden ja tutkimustiedon rooli lainsäädännön uudistamisen prosessissa ja miten viranomaiset ja poliitikot ottivat vastaan tietoa ja hyödynsivät sitä.

\section{TYTTÖJEN SUKUELINTEN SILPOMINEN}

\section{TYTTÖJEN SUKUELINTEN SILPOMISPERINNE}

Tyttöjen sukuelinten silpomisella tarkoitetaan tytön sukuelinten vahingoittamista, osittaista poistamista ja/tai kudosten yhteen ompelemista. Tavallisin silpomisikä on 4-10 vuotta. Silpomiselle ei ole olemassa lääketieteellisiä perusteita. Se on vanha kulttuurinen perinne, jota harjoitetaan edelleen erityisesti Afrikassa, Lähi-idässä ja Aasiassa. Tietyt uskonnon tulkinnat ylläpitävät perinteen jatkumista, vaikka mikään uskonto ei sinällään vaadi tai edellytä silpomista. Silpomisen on ajateltu suojelevan tyttöä ja valmistavan avioliittoon. (1.)

\section{TYTTÖJEN JA NAISTEN SILPOMISEN YLEISYYS}

Muuttoliikkeen myötä silpomisperinne on levinnyt ympäri maailmaa. Uusimman arvion mukaan 92 maassa eri puolilla maailmaa asuu silpomisen läpikäyneitä tai silpomisvaarassa olevia tyttöjä tai naisia. Näistä 32 maassa, pääosin Afrikan maita, on saatu tietoa silpomisen yleisyydestä edustavista väestökyselyistä. Tämän lisäksi 31 maassa on tehty olemassa olevien aineistojen ja tilastojen perusteella arvioita ja 15 maassa pieniä, yksittäisiä tutkimuksia silpomisen yleisyydestä. Neljässätoista maassa näiden edellä mainittujen lisäksi on dokumentoitu tapahtuvan silpomista tai olevan silpomisen läpikäyneitä tyttöjä tai naisia. (2.)

\section{MITÄ TIETOA SUKUELINTEN SILPOMISESTA OLI KÄYTETTÄVISSÄ ENNEN LAINUUDISTUKSEN ALOITTAMISTA?}

Euroopan tasa-arvoinstituutti (EIGE) kehotti kaikkia jäsenmaita arvioimaan maassa asuvien silpomisen läpikäyneiden ja silpomisvaarassa olevien määriä käyttäen hyväksi tilastoja silpomisperinnettä harjoittavista maista lähtöisin olevista ja tietoa silpomisen yleisyydestä eri ikäryhmissä (3). Teimme arvion ja julkaisimme sen tyttöjen ja naisten silpomisen vastaisessa toimintaohjelmassa vuonna 2019 (4).

Laskelmien mukaan Suomessa asuisi mahdollisesti noin 10000 silpomisen läpikäynyttä tyttöä ja naista. Vaarassa joutua silvotuksi voisi olla noin 650 tyttöä, jos silpomisperinteen uskotaan katkeavan Suomeen muuton myötä. Jos silpomisperinteen ajatellaan jatkuvan Suomeen muuton jälkeen, voisi riskissä olla noin 3000 tyttöä. Arviot ovat kaikissa maissa hyvin karkeita ja niissä on iso vaihteluväli. (4.) 
Riskiarvion lisäksi tietoa oli saatavissa Maahanmuuttajien terveys- ja hyvinvointitutkimuksen (Maamu), Ulkomaista syntyperää olevien työ- ja hyvinvointitutkimuksen (UTH) ja Turvapaikanhakijoiden terveys- ja hyvinvointitutkimuksen (TERTTU) sekä syntyneiden lasten rekisterin perusteella.

Vuonna 2010-2012 Suomessa asuvista somalitaustaisista naisista noin 70 prosenttia ja kurditaustaisista noin 30 prosenttia raportoi läpikäyneensä silpomisen. Silpominen oli sitä yleisempää mitä vanhempi nainen oli. (5.) UTH-tutkimuksessa vuonna 2014 noin 19 prosenttia niistä naisista, jotka olivat lähtöisin silpomisperinnettä harjoittavista maista, kertoi olevansa silpomisen läpikäynyt (6). TERTTU-tutkimuksessa noin 11 prosenttia turvapaikkaa vuonna 2018 Suomesta hakeneista naisista kertoi läpikäyneensä silpomisen. Yhdenkään turvapaikkaa hakeneen alle 12vuotiaan tytön ei raportoitu läpikäyneen silpomista. (7.)

Syntyneiden lasten rekisteriin oli vuonna 2017 raportoitu silpomisen läpikäyneitä synnyttäjiä yhteensä 118 eli 0,2 prosenttia synnyttäjistä. Kaksi kolmasosaa silpomisen läpikäyneistä synnyttäjistä oli alle 30-vuotiaita ja 9 prosentille oli tehty avausleikkaus. Helsingin ja Uudenmaan sairaanhoitopiirin (HUS)-alueen tiedot puuttuivat, sillä HUS ei pystynyt toimittamaan tietoa rekisteriseurantaan. (8.)

Yllämainittujen silpomisen yleisyyttä Suomessa koskevien tietojen lisäksi oli tiedossa, että silpomisen lopettamiseksi tarvitaan silpomisen kieltävä lainsäädäntö. Kansainvälisten kokemusten perusteella ei ole niinkään merkitystä sillä, minkälaisella lailla sääntely on hoidettu. Tiedettiin myös, että ehkäisevässä työssä tehokkainta on ammattilaisten kouluttaminen ottamaan asia puheeksi ja yhteistyön tekeminen kohderyhmän kanssa lisäten kohderyhmän tietoisuutta asian haitallisista vaikutuksista ja sitä koskevasta lainsäädännöstä.

Tiedossa oli myös, että perinnettä harjoittavista maista lähtöisin olevien asennoituminen silpomiseen muuttuu Suomeen muuton myötä: he asennoituivat 2000-luvun alussa selvästi kielteisemmin silpomiseen kuin 1990-luvulla $(9,10)$. Tutkija oli toiveikas sen suhteen, että perinteestä luovutaan kokonaan. Tuoretta kattavaa tutkimusta silpomisperinteeseen suhtautumisesta ei ollut käytettävissä.

\section{SILPOMISTA KOSKEVA LAINSÄÄDÄNTÖ}

\section{SILPOMISEN RANGAISTAVUUS NYKYLAINSÄÄDÄNNÖSSÄ SUOMESSA}

Tyttöjen sukuelinten silpominen on Suomessa rangaistavissa rikoslain perusteella. Sen mukaan tyttöjen sukuelinten silpominen voidaan tulkita joko pahoinpitelyksi tai törkeäksi pahoinpitelyksi. Jos kyseessä on pahoinpitely, teosta voi seurata sakkoa tai kaksi vuotta vankeutta. Törkeäksi pahoinpitelyksi luokitellusta silpomisesta voi seurata 2-10 vuotta vankeutta. Rikoksen vanhenemisaika on 20 vuotta. (11.) Myös lapsen lähettäminen toiseen maahan, silpomisessa avustaminen ja silpomisen valmistelu ovat rangaistavia tekoja $(12,11)$.

Suomen poliisille tulee vuosittain muutamia tyttöjen sukuelinten silpomista koskevia rikosilmoituksia (13). Suomessa on ollut vain yksi oikeustapaus vuonna 2019, jossa ei annettu tuomiota näytön puuttumisen vuoksi. Sekä tutkijat että ehkäisevää työtä tekevät ovat pohtineet, onko syy oikeustapausten vähyyteen ja tuomioiden puuttumiseen siinä, ettei silpomista tapahdu vai se, etteivät teot tule viranomaisten tietoon.

Fenix ry julkaisi vuonna 2017 selostuksen neljästä 18-23-vuotiaasta naisesta, jotka oli lapsena, 9-15 vuotta aikaisemmin viety Suomesta ulkomaille silpomista varten. (14). Teot eivät olleet vielä rikoksena vanhentuneet, mutta niistä ei tehty rikosilmoituksia. Selostus on ainoa dokumentti siitä, että Suomesta on viety tyttöjä muualle silpomista varten.

\section{LAINSÄÄDÄNTÖ MUUALLA}

Maailmanlaajuisesti yhdeksässä maassa muun muassa Ruotsissa ja Iso-Britanniassa on tyttöjen ja naisten sukuelinten silpomisen kieltävä kansallinen erillislaki. Näiden lisäksi silpomisen kieltäminen on erikseen mainittu 44 maan lainsäädännössä. Näin on muun muassa Norjassa, Tanskassa ja Virossa. Silpomisen estämistä ei ole erikseen mainittu 41 maan lainsäädännössä. Näitä maita ovat Suomen lisäksi esimerkiksi Ranska ja Hollanti. Ruotsissa oikeustapauksia on ollut 11, joista kahdessa on annettu tuomio. Ranskassa on langetettu useita tuomioita. (2.) 


\section{KANSALAISALOITTEESTA LAKIVALIOKUNTAAN JA TAKAISIN EDUSKUNTAAN}

\section{KANSALAISALOITE TYTTÖJEN JA NAISTEN SUKUELINTEN SILPOMISESTA}

Kansalaisaloitteen tyttöjen ja naisten sukuelinten silpomisen kieltävästä erillislaista allekirjoitti yli 61000 henkilöä ja aloite jätettiin eduskunnalle kesäkuussa 2019. Aloitteessa todettiin silpomisen olevan jo nykylainsäädännössä rangaistavaa. Erillislain tarvetta perusteltiin sillä, etteivät kaikki vanhemmat pidä silpomista pahoinpitelynä ja että ammattilaiset tarvitsevat erillislakia ehkäisevän työn tueksi. Laki olisi viesti siitä, ettei silpomista hyväksytä. (15.)

Syyskuussa 2019 kansalaisaloitteesta käytiin eduskunnassa 36 puheenvuoroa sisältänyt lähetekeskustelu. Käytetyissä puheenvuoroissa esiintyi virheellistä tietoa kuten maininta: "Suomi on ainoa Pohjoismaa, jossa naisten sukupuolielinten silpominen ei ole lailla kiellettyä.” Keskustelun jälkeen aloite lähetettiin lakivaliokunnan käsittelyyn.

\section{PROSESSI LAKIVALIOKUNNASSA}

Lakivaliokunta kuuli erittäin laajasti eri toimijoita - tutkijoita, ehkäisevää työtä tekeviä, lukuisia eri järjestöjä, ammattilaisia, uskonnollisia johtajia ja virkamiehiä. Kuultuaan Terveyden ja hyvinvoinnin laitoksen (THL) tutkijoita lakivaliokunnalla oli tiedossa, että THL:Ita oli vielä kuulemisten jälkeen tulossa uutta tietoa aiheesta.

Toimitimme lakivaliokunnalle tuoreet tutkimustulokset heti niiden ilmestyttyä. Syntyneiden lasten rekisteriin oli raportoitu 167 uutta silpomisen läpikäynyttä synnyttäjää. Synnyttäjien profiili oli hyvin samanlainen kuin vuonna 2017 eikä nytkään raportoitu yhtään Suomessa syntynyttä silpomisen läpikäynyttä synnyttäjää eivätkä HUS:n tiedot olleet edelleenkään käytettävissä. Ulkomaalaistaustaisille suunnatussa FinMonik-tutkimuksessa 11 prosenttia niistä naisista, jotka olivat tulleet 27 sellaisesta maasta, joissa silpomisperinne elää, raportoi läpikäyneensä silpomisen (16).

Kouluterveyskyselyssä vuonna 2019 vastanneista tytöistä 80 ilmoitti läpikäyneensä sukuelinten silpomisen (kyselyssä käytettiin termiä ympärileikkaus) ja 135 oli epävarmoja asiasta (17). Aineiston perusteella oli vaikea sanoa, kuinka todennäköistä oli, että kaikki silpomiskysy- mykseen vastanneet olivat ymmärtäneet, mitä kysymyksellä tarkoitettiin ja olivatko vastanneet oikein siihen sekä omaa ja vanhempiensa syntymämaata koskeviin kysymyksiin. Tulokset herättivät niin paljon median ja sosiaalisen median huomiota, että saimme perustella näkemyksiämme useita kertoja $(18,19)$.

Lakivaliokunta viimeisteli mietintönsä vasta, kun oli saanut viimeisetkin tutkimustulokset käyttöönsä. Mietintö julkaistiin syyskuussa 2020 ja siinä todettiin, että rikosoikeudellisesti Suomessa ei ole sukuelinten silpomisen suhteen ongelmaa. Ongelmalliseksi katsottiin tilanne, jossa teko tehdään ulkomailla ja tekijänä on henkilö, joka ei ole Suomen kansalainen eikä asu Suomessa. Mietinnössä todettiin, että ensiarvoisen tärkeää ovat käytännön ehkäisevät toimenpiteet. Lakivaliokunta ei suositellut erillislakia mutta suositteli asian viemistä eduskunnalle tarkentavan lainvalmistelutyön aloittamiseksi. (20.)

Eduskunnan täysistunnossa 4.11.2020 käytiin jälleen monen tunnin mittainen keskustelu aiheesta. Puheenvuoroissa ei tällä kertaa ollut niin paljon asiavirheitä kuin lähetekeskustelussa vuosi aikaisemmin, mutta kaikille kansanedustajille asia ei vieläkään ollut täysin selvä. Esimerkiksi silpomisen yleisyydestä, tutkimuksesta tai tilastoinnista eikä etenkään silpomisen eteen tehdystä työstä ollut läheskään kaikilla oikeaa tietoa. 6.11.2020 eduskunta hyväksyi asian viemisen valtioneuvoston käsittelyyn lainvalmistelua varten.

\section{LAINSÄÄDÄNNÖN UUDISTAMISESSA MUKANA OLLEET TOIMIJAT}

Prosessissa oli mukana lukuisia eri toimijoita: useita järjestötoimijoita, viranomaisia, poliitikkoja, eri alojen ammattilaisia ja asiantuntijoita, tutkijoita, toimittajia ja sosiaalisen median toimijoita. Kansalaisaloite lähti liikkeelle Finlaysonin ja kansalaisyhteistyöjärjestön yhteistyönä. Perinteiset, pitkään silpomisen vastaista työtä Suomessa tehneet järjestöt eivät osallistuneet kansalaisaloitteeseen, vaikka eivät varsinaisesti vastustaneet sitä, mutta katsoivat nykylainsäädännön olevan riittävä.

Poliitikot olivat aktiivisia toimijoita tehden muun muassa lakialoitteita ja kirjallisia kysymyksiä, osallistuen erilaisiin kannanottoihin, kommentoimalla asiaa mediassa, keskustelemalla tutkijoiden ja yhteisön edustajien kanssa sekä osallis- 
tumalla sosiaalisen median keskusteluihin. Eduskunnassa asia herätti runsaasti keskustelua. Media oli myös hyvin aktiivinen toimija - keskusteluja aiheesta käytiin niin netti-, päivä- kuin viikkolehtien sivuilla, yleisradiossa ja eri televisiokanavilla.

Ihmisoikeusliitto ylläpitää eri toimijoiden, asiantuntijoiden ja viranomaisten verkostoa, niin sanottua FGM-verkostoa, jossa myös käsiteltiin silpomiseen liittyvää lainsäädäntöä. Erilaiset järjestöt ja perinnettä harjoittavat yhteisöt järjestivät muun muassa paneelikeskusteluja ja seminaareja, joissa käytiin vilkkaasti keskustelua lainsäädännön tarpeellisuudesta.

THL ja sosiaali- ja terveysministeriö ovat vuodesta 2013 asti järjestäneet vuosittain työkokouksen osana tyttöjen ja naisten silpomisen estämisen toimintaohjelman toteuttamista. Työkokous on kaikille avoin mutta tarkoitettu pääosin ammattilaisille, tutkijoille, viranomaisille ja opiskelijoille yhteistyön kehittämiseksi ja tietojen vaihtamiseksi. Näissä työkokouksissa esitellään uusin tutkittu tieto tyttöjen ja naisten sukuelinten silpomisesta ja on useita kertoja esitelty silpomista koskeva lainsäädäntö ja ammattilaisten ilmoitusvelvollisuudet.

\section{POHDINTA}

Kansalaisaloitteen ansiosta tyttöjen ja naisten silpomisesta keskusteltiin ja kirjoitettiin vuonna 2020 ehkä enemmän kuin siihen mennessä yhteensä. Koska kansalaisaloite päätyi käsiteltäväksi ja sen pohjalta lähdettiin valmistelemaan lainsäädäntöä, sitä voidaan epäilemättä pitää onnistuneena, vaikka lakivaliokunta ei katsonutkaan tarpeelliseksi kansalaisaloitteen ehdottamaa erillislakia. Ohjasiko prosessia tieto ja mikä oli tutkijoiden ja tutkimuksen rooli prosessissa?

Meillä ei ole tietoa siitä, kuinka hyvin kansalaisaloitteen allekirjoittajat olivat perillä silpomisesta ja sitä koskevasta lainsäädännöstä. Sattumoisin minuakin pyydettiin allekirjoittamaan kansalaisaloite vaatetusliikkeessä asioidessani, "koska Suomessa tätä ei ole kielletty". Kerroin myyjälle pitäväni asiaa erittäin tärkeänä, mutta sen olevan jo lailla kiellettyä Suomessa, mihin hän topakasti totesi "Ei ole. Nythän sitä lakia vasta ollaan tekemässä”. En varmaan ollut ainoa, jota näin johdettiin harhaan väärällä tiedolla. Suomen nykyinen lainsäädäntö olisi ollut riittävä silpomisen rankaisemiseksi ja ehkäisevän työn tueksi (21). Sen sijaan silpomista ehkäisevälle työlle osoitetut voimavarat eivät ole olleet riittävät. Istanbulin sopimuksen toimeenpanoa arvioivan Grevion raportissa todettiin, että Suomen lainsäädännön riittävyyttä rikoksen avunantoon ja yllytykseen olisi tarpeen arvioida (21).

Eduskunnassa syksyllä 2019 käyty lähetekeskustelu osoitti, että kansanedustajilla ei ollut riittävästi tietoa asiasta ja osa jakoi keskustelussa virheellistä tietoa. Aiheeseen olisi ollut helppo perehtyä esimerkiksi THL:n nettisivujen avulla. Silpomisen estämisen toimintaohjelma oli myös jo tuolloin päivitetty (4). Myös tutkittua tietoa olisi ollut helposti saatavilla. Tutkijalle jäi sellainen tuntuma, että osa poliitikoista otti olemassa olevasta tiedosta käyttöönsä sen, mikä parhaiten palveli heidän omia näkemyksiään.

Sen sijaan aiheen käsittely lakivaliokunnassa oli erittäin perusteellista ja tutkimusta ja tutkijoita kunnioittavaa. Ennen mietintönsä antamista lakivaliokunta odotti vielä viimeiset tutkimustulokset ja esitti ne oikein sekä mietinnössä että eduskunnan täysistunnossa syksyllä 2020. Lakivaliokunta toivoi mietinnössään, että Kouluterveyskyselyssä jatkossakin kysyttäisiin asiasta. Olimme tutkimusryhmässä jo päättäneet luopua kysymyksestä siihen liittyvien tulkintaongelmien vuoksi, mutta mietinnön jälkeen päätimme lisätä kysymyksen vuoden 2021 tiedonkeruuseen. Lakivaliokunta kunnioitti tutkijoita ja tutkijat lakivaliokuntaa.

Kaikki silpomiseen liittyvä kirjoittelu ja keskustelu ei ollut tietoon tai tutkimukseen perustuvaa, vaan osin jopa tietoista vastakkainasettelua ja tiedon tai tutkijoiden sanomisten vääristelyä tai tahalliselta tuntuvaa väärinymmärrystä. Ruotsissa on todettu sensaatiohakuisen kirjoittamisen ja keskustelun silpomisesta voivan johtaa siihen, että asiasta on entistä vaikeampi puhua yhteisöissä (22). Näin ollen aiheen saama julkisuus voi kääntyä ehkäisytyötä vastaan.

Silpomisperinteestä luopumisessa olisi oleellista saada silpomisen läpikäyneiden naisten ääni kuuluville. Koska asia on hyvin sensitiivinen ja Suomessa rikoksena tuomittava, tutkijoiden on vaikea saada haastateltavia $(10,23,24)$. Jos haastattelujen yhteydessä selviäisi, että joku haastateltavista olisi alaikäisenä, Suomessa jo asuessaan läpikäynyt silpomisen eikä rikos olisi vielä vanhentunut, joutuisi tutkija eettisen ongelman eteen - hän tietäisi rikoksesta ja ehkä rikok- 
sen tekijästäkin, mutta mitä todennäköisimmin rikoksen uhri ei haluaisi viedä asiaa tutkittavaksi. Viranomaisten ja ammattilaisten tulisi olla niin hyvin koulutettuja ja tietoisia, että he tunnistaisivat silpomisen riskissä olevat tytöt ja silpominen voitaisiin estää. Tähän kulminoituukin silpomisen ja sitä säätelevän lainsäädännön suurin ongelma. Kansalaisaloitteella haettu tiukempi rangaistavuus ehkä pikemminkin hiljentää kuin auttaa uhreja kertomaan asiasta. Lisäksi nykyinen lainsäädäntö mahdollistaa jo ehkäisevän työn, kunhan ammattilaiset ovat riittävän hyvin koulutettuja.

Ehkäisytyössä oleellista on tehdä yhteistyötä perinnettä harjoittavien yhteisöjen kanssa. Lainsäädäntöä tärkeämmäksi yhteisöjen keskuudessa on nähty ihmisissä itsessään tapahtuva asennemuutos lisääntyneen ymmärryksen kautta (10). Asennemuutostyössä tarvitaan myös tutkijan ja ammattilaisen ymmärryksen lisääntymistä.

\section{LOPUKSI}

Tutkijan työssä saa parhaimmillaan tutkia itseään kiinnostavia asioita. Jokainen tutkija varmasti toivoo, että tutkimustulokset kiinnostaisivat myös muita ja että tuloksilla olisi vaikuttavuutta - niitä voitaisiin käyttää tiedolla johtamiseen.

Vaikka meillä Suomessa on edelleen vähän tietoa silpomisen yleisyydestä, on sitä kuitenkin kansainvälisesti tarkasteltuna kiitettävästi. Silpomisen yleisyyttä on tutkittu useissa väestötutkimuksissa. Silpomisesta kerätään tietoa osana syntyneiden lasten ja hoitoilmoitusrekisterin tiedonkeruuta. Silpomisesta saadaan tietoa myös poliisin rekistereistä. Siitä tullaan kysymään terveydenhuollon ammattilaisilta osana Neuvola- ja kouluterveydenhuollon selvitystä ja nuorilta osana Kouluterveyskyselyä.

Toki tiedonkeruuta pitää aina myös kehittää. Syntyneiden lasten rekisteriin pitäisi saada puuttuvat HUS-alueen tiedot. Potilastietojärjestelmiin tulisi rakenteisesti kerätä tietoa silpomisesta, jotta saisimme tietoa siitä, kuinka usein ammattilaiset ottavat asian puheeksi. Tehdyistä lastensuojeluilmoituksista olisi myös hyvä saada tilastotietoa. Aiheesta tarvittaisiin myös lisää laadullista tutkimusta kuten tietoa asenteista silpomista kohtaan (25) ja silpomisen läpikäyneiden kokemuksista.

Tutkimustiedon tulisi saavuttaa paitsi poliittiset päättäjät, ammattilaiset, järjestötoimijat ja tutkijayhteisö myös perinnettä harjoittavat yhteisöt. Tutkijoina olisikin hyvä olla myös yhteisöjen edustajia. Arkaluontoisen aiheen tutkimuksen ja siihen liittyvän silpomisen estämistyön tulisi olla erityisen kunnioittavaa ja asiakaslähtöistä - tapahtua aidossa dialogissa.

Toivottavaa olisi, että eduskunnassa käytetyt lukuisat puheenvuorot päätyisivät myös tekoihin niin, että tutkimukseen ja ehkäisytyöhön olisi jatkossa riittävät resurssit kansallisella ja alueellisella tasolla sekä kolmannella sektorilla.

Jos lainsäädäntö uudistuu, sen vaikuttavuuden arviointi on ensiarvoisen tärkeää. Tulee olemaan vaikeaa erottaa lainsäädännön vaikutuksia siitä työstä, jota on jo tehty kahden toimintaohjelman aikana $(26,4)$ ja jo ennen niitä. Ehkäisytyö on hidasta ja tulokset näkyvät vasta vuosien kuluttua.

\section{LÄHTEET}

(1) WHO. Key facts.2020. https://www.who. int/news-room/fact-sheets/detail/femalegenitalmutilation

(2) Female genital mutilation/cutting: A call for a global response. End FMG/C. Raportti 2020. https://www.endfgm.eu/editor/ files/2020/03/FGM_Global_-_ONLINE_PDF_ VERSION_-_06_2.pdf

(3) EIGE, European Institute for Gender Equality, Estimation of girls at risk of female genital mutilation in the European Union, June 2015. https://eige.europa.eu/publications/estimationgirls-risk-female-genital-mutilation-europeanunion-report

(4) Koukkula M, Klemetti R. Tyttöjen ja naisten sukuelinten silpomisen (FGM) estämisen toimintaohjelma. Sosiaali- ja terveysministeriön julkaisuja 2019:1.

(5) Koukkula M, Keskimäki I, Koponen P ym. Female genital mutilation/cutting among women of Somali and Kurdish origin in Finland. Birth. 2016;43:240-246. https://doi.org/10.1111/birt.12236

(6) Koponen P, Jokela S, Skogberg N ym. Terveys. Ulkomaalaistaustaiset kokevat terveytensä hyväksi, mutta terveysongelmien yleisyydessä on suuria eroja. Kirjassa: Nieminen T, Sutela H, Hannula U (toim.), Ulkomaista syntyperää olevien työ ja hyvinvointi Suomessa. Helsinki:Tilastokeskus. 2015; 151-162.

(7) Koukkula M, Klemetti R. Sukuelinten silpominen ja ympärileikkaukset. Kirjassa: Skogberg N, Mustonen K-L, Koponen P ym. (toim.). Turvapaikanhakijoiden terveys ja hyvinvointi - Tutkimus Suomeen vuonna 2018 tulleista turvapaikanhakijoista. Raportti 12/2019. Helsinki. Terveyden ja hyvinvoinnin laitos; 2019. 
(8) Syntyneiden lasten rekisteri, 2017. Terveyden ja hyvinvoinnin laitos, 2018.

(9) Mölsä, M. Tyttöjen ympärileikkauksen hoito ja ehkäisy Suomessa. Helsinki: Stakes, 1994.

(10) Mölsä. M. Ajat ovat muuttuneet - Selvitys tyttöjen ja naisten ympärileikkaukseen liittyvistä asenteista ja aikeista pääkaupunkiseudulla asuvien maahanmuuttajien keskuudessa. Ihmisoikeusliitto ry. KokoNainen-projekti. 2004. PDF dokumentti. https://ihmisoikeusliitto.fi/wpcontent/uploads/2014/10/ajatovatmuuttuneet.pdf

(11) Rikoslaki 01.01.1891. 39/1889: 21; 6\$ ja 7\$. https://www.finlex.fi/fi/laki/ smur/1889/18890039001

(12) Rikoslaki 01.01.1891. 39/1889: 3, 3\$. https://www.finlex.fi/fi/laki/ smur/1889/18890039001

(13) Henkilökohtainen tiedonanto Måns Enqvist, 27.10. 2020

(14) Ahmed U, Ylispangar E. Selvitys Suomessa syntyneiden tyttöjen ympärileikkauksesta 28.9.2017. Fenix Helsinki Ry. https://www. fenixhelsinki.com/l/selvitys-suomessasyntyneiden-tyttojen-ymparileikkauksesta/

(15) Kansalaisaloite tyttöjen ja naisten silpomisen estämiseksi. 2.4.2018. OM75/52/2018. https:// www.eduskunta.fi/FI/vaski/EduskuntaAloite/ Documents/KAA_1+2019.pdf.

(16) Koukkula M, Klemetti R. Naisten sukuelinten silpominen ja miesten ympärileikkaus. Kirjassa: Kuusio H, Seppänen A, Jokela S ym. (toim.) Ulkomaalaistaustaisten terveys ja hyvinvointi Suomessa. FinMonik-tutkimus 2018-2019. Terveyden ja hyvinvoinnin laitos. Raportti $1 / 2020$. http://urn.fi/URN:ISBN:978-952-343-034-1

(17) Koukkula M, Gissler, M, Ikonen R ym. Tyttöjen ja naisten ympärileikkaus: Esiintyvyys Kouluterveyskyselyssä ja syntyneiden lasten rekisterissä. Tutkimuksesta tiiviisti -julkaisu. Terveyden ja hyvinvoinnin laitos, 2020. http://urn.fi/URN:ISBN:978-952-343-514-8.

(18) Klemetti R, Koukkula M; Ikonen,R. Miten tyttöjen sukuelinten silpomisesta saataisiin luotettavasti tietoa? Blogi 11.6.2020. Terveyden ja hyvinvoinnin laitos, 2020. https://blogi.thl. fi/miten-tyttojen-sukuelinten-silpomisestasaataisiin-luotettavasti-tietoa/
(19) Koukkula M, Mohamed F, Klemetti M. Silpomisen ehkäisy voi onnistua vain tiiviillä yhteistyöllä. Blogi 13.8.2020. Terveyden ja hyvinvoinnin laitos, 2020. https://blogi.thl.fi/ silpomisen-ehkaisy-voi-onnistua-vain-tiiviillayhteistyolla/

(20) Lakivaliokunnan mietintö LaVM 6/2020 vp- KAA 1/2019 vp. Eduskunta, 2020. https:// www.eduskunta.fi/FI/vaski/Mietinto/Documents/ LaVM_6+2020.pdf

(21) GREVIO. Baseline Evaluation Report. Finland.2019. https://1586428.168.directo.fi/@ Bin/a2a88976dd6feef71a88cd416935d3e6/ 1604511393/application/pdf/8238232/ GREVIO\%20report\%20on\%20Finland.pdf.pdf

(22) Johnsdotter, S. Created by God: How Somalis in Swedish Exile Reassess the Practice of Female Circumcision. Lund: Department of Sociology, Lund University, 2002.

(23) Niskala S. Hiljaisuuden noidankehä - tyttöjen ja naisten ympärileikkausperinne maahanmuuttajamiesten haastatteluissa. Tampereen yliopisto, Terveystieteiden yksikkö, Kansanterveystiede. Pro gradu, 2015.

(24) Väkiparta M. Young men against female genital mutilation/cutting in Somaliland : Discursively negotiating violence, gender norms and gender order. Väitöskirja, Helsingin yliopisto. http://hdl. handle.net/10138/307401

(25) Mohamed AH \& Latvala J. (2020) Female genital mutilation (FGM). Awareness and perceptions of Somali men in the Helsinki region, Finland. Finnish League for Human Rights. Ihmisoikeusliitto, 2020. https://ihmisoikeusliitto. fi/wp-content/uploads/2020/09/FGM-Awarenessand-perceptions-of-Somali-men-in-the-Helsinkiregion.pdf

(26) Sosiaali- ja terveysministeriö 2012. Tyttöjen ja naisten ympärileikkauksen estämisen toimintaohjelma 2012-2016 (FGM). Julkaisuja 8/2012. Helsinki: Sosiaali- ja terveysministeriö. https://julkaisut.valtioneuvosto.fi/bitstream/ handle/10024/72751/URN\%3ANBN\%3Afife201504226213.pdf? sequence $=1$

\section{Reija Klemetti}

FT, Dosentti, tutkimuspäällikkö

Terveyden ja hyvinvoinnin laitos 